\title{
Phenol content and antioxidant activity in seaweed fermented with lactic acid bacteria
}

\author{
Sumardianto, Riyadi, P.H., Anggo, A.D., Romadhon and *Rianingsih, L. \\ Department of Fisheries Product Technology, Diponegoro University, Semarang, Central Java, Indonesia.
}

\author{
Article history: \\ Received: 10 February 2021 \\ Received in revised form: 16 \\ April 2021 \\ Accepted: 19 April 2021 \\ Available Online: 28 July \\ 2021
}

Keywords:

Phenol,

Antioxidant,

Seaweed,

Fermentation,

Lactic acid bacteria

DOI:

https://doi.org/10.26656/fr.2017.5(S3).006

\begin{abstract}
Antioxidants and antimicrobials are rich in seaweed. Seaweed has been used as food for a long time and the potency to be used as a functional food. One of the most versatile foods is fermented beverages. Fermentation can increase the amount of antioxidants. This study aims to determine seaweed (Gelidium sp. and Eucheuma cottonii) extract fermentation with lactic acid bacteria (LAB), namely Lactobacillus plantarum and Lactobacillus acidophilus, as a starter on phenol content and antioxidant activity. The method used was an experimental laboratory. The seaweed was obtained from Yogyakarta. Seaweed extract was given a LAB starter and then fermented for $24 \mathrm{hrs}$. The samples were analyzed before and after fermentation in parameter reducing sugar, TPC, LAB viability, $\mathrm{pH}$, phenol content, and antioxidant activity $\mathrm{IC}_{50}$ tests. The result showed that both in Gelidium sp. and Eucheuma cottonii, reducing sugar does not change before and after fermentation with the LAB starter. Fermentation could increase the TPC, LAB viability, phenol content, antioxidant activity $\mathrm{IC}_{50}$, and lower the $\mathrm{pH}$ sample. Eucheuma cottonii fermented with $L$. acidophilus gives the best characteristic of antioxidant.
\end{abstract}

\section{Introduction}

Algae or seaweed is commonly consumed in Asia (Aparicio et al., 2018). Algae are an important natural source of bioactive like polyphenols, carotenoids, vitamins, proteins, lipids, and polysaccharides (Rodrigues et al., 2016; Suleria et al., 2016; Mittal et al., 2017; Zhao et al., 2018; Cui et al., 2019; Ozturk et al., 2020) and have acted as an antioxidant as well as antibacterial (Roohinejad et al., 2017).

There are numerous seaweed species and have not been used optimally. Seaweed growth does not compete with agricultural land (Hou et al., 2017). Parada et al. (2019) reported that polyphenol could be utilized as an ingredient to make novel low glycemic response food.

Seaweed consumption is currently showing an increasingly interesting trend because humans are more concerned with healthy lifestyles. Many products from marine products are made and marketed as functional foods (Roohinejad et al., 2017). Seaweed stock is abundant, and the price is low. Microorganisms can ferment seaweed to increase the bioactive component (Suraiya et al., 2018).

The fermented product of seaweed has not been widely studied. Fermentation using lactic acid bacteria was reported in 2004 on Ulva spp. Besides, the Chlorophyta, Phaeophyta, and Rhodophyta groups have also been studied. Fermentation of either lactic acid or ethanolic makes the possibility of the making new fermented product (food and beverage) from seaweed and seagrass (Uchida et al., 2017). Gelidium sp. and Eucheuma cottonii are edible seaweed and abundant in Indonesia.

Antioxidants and antimicrobials are rich in seaweed. Seaweed has been used as food for a long time and has the potency to be used as a functional food. One of the functional foods is fermented drinks. Fermentation can increase antioxidants. This research focused on studying the development of the fermented product from seaweed using lactic acid bacteria. The purpose of this study was to determine the effect of lactic acid bacteria (Lactobacillus plantarum and Lactobacillus acidophilus) as a starter on phenol content and antioxidant activity during fermentation of Gelidium and Eucheuma cottonii extract. 


\section{Materials and methods}

\subsection{Material}

Dried Gelidium sp. and Eucheuma cottonii were purchased from Gunung Kidul Yogyakarta, Indonesia. Natrium Chloride, Man Rogosa Sharpe media, Plate Count Agar, Natrium Azide, $\mathrm{CaCO}_{3}$, DPPH, Methanol, Alcohol, Follin Denish, $\mathrm{Na}_{2} \mathrm{CO}_{3}$, Arsenomolibdat, Folin reagent, Nelson reagent. Starter preparation: The bacterial starters used in this study were L. acidophilus FNCC-0051, and L. plantarum FNCC0027 obtained from Pusat Studi Pangan dan Gizi UGM. The starter was subjected to subculture twice in sterile MRS broth media then incubated at $37^{\circ} \mathrm{C}$ for $24 \mathrm{hrs}$ before use.

\subsection{Seaweed extract fermentation}

This research was conducted as described by Rianingsih and Sumardianto (2020). Seaweed Gelidium sp. and Eucheuma cottonii was soaked in water for 6 hrs and then chopped into approximately $1 \mathrm{~cm}$ in length. Each seaweed extract was put into a soymilk maker and added with mineral water. The ratio of seaweed and water was 1:12. Each seaweed extract was added with glucose $5 \% \mathrm{w} / \mathrm{v}$ and put in a glass jar approximately 200 $\mathrm{mL}$, then sterilized in autoclave $121^{\circ} \mathrm{C} 15$ mins. The seaweed extract allowed to cool and, after the temperature below $40^{\circ} \mathrm{C}$ then added with a $5 \%$ bacterial starter (L. acidophilus or L. plantarum) incubated $24 \mathrm{hrs}$ at $37^{\circ} \mathrm{C}$.

\subsection{Measurement of reducing sugar}

The reducing sugar was determined following Martin et al. (2000). Aquadest was used to add one gram of sample until the volume reached $100 \mathrm{~mL}$. The solution was mixed with Reagent Nelson and heated in a water bath for 30 minutes at $100^{\circ} \mathrm{C}$. Allow the solution to cool before adding arsenomolibdat. At $540 \mathrm{~nm}$, absorbance was measured.

\subsection{Measurement of $\mathrm{pH}$}

The $\mathrm{pH}$ was determined directly using a $\mathrm{pH}$ meter.

\subsection{Measurement of TPC and viability of lactic acid} bacteria

Determination of TPC and viability of lactic acid bacteria were determined as described by Dissarapong et al. (2005). Total plate counts were determined using a plate count agar, and the dilution was using $0.85 \% \mathrm{NaCl}$ sterile solution. A diluted sample $(0.1 \mathrm{~mL})$ was spread on the media's surface and incubated at $37^{\circ} \mathrm{C}$. While lactic acid bacteria count was determined using Man Rogosa Sharpe agar (MRSA), and the dilution was using $0.85 \%$
$\mathrm{NaCl}$. A diluted sample $(1 \mathrm{~mL})$ was poured into a petri dish and followed by 10 to $15 \mathrm{~mL}$ of MRSA media. Incubation was carried out at $37^{\circ} \mathrm{C}$ for $48 \mathrm{hrs}$.

\subsection{Measurement of phenol}

The total phenolic content was determined using the Folin-Ciocalteu method described by Saravanan and Parimelazhagan (2014). Gallic acid was used to prepare a standard calibration curve.

\subsection{Measurement of antioxidant activity}

The samples' free radical activity was carried out using the 2,2-diphenyl-1-picrylhydrazyl (DPPH) assay described by (Tanod et al., 2019).

\subsection{Statistical analysis}

A completely randomized design was used throughout this study, and the experiments were done in triplicate. Data were subjected to analysis of variance (ANOVA), and mean comparison was carried out using the honest significance difference (HSD) test. Statistical analysis was performed using the Statistical Package for Social Sciences (SPSS for Windows; SPSS Inc.).

\section{Results and discussion}

\subsection{Reducing Sugar}

Microorganism, including bacteria, need media or nutrition to grow. Bacteria use food and convert it to energy, grow to produce several metabolites. Like reducing sugar, the carbon source is the primary energy source (Singh et al., 2017). Component carbon and nitrogen sources usually play a crucial role in the fermentation medium (Khani et al., 2016). The increasing yield of the cell during fermentation is influenced by carbon sources (Wang et al., 2018).

Reducing sugar on 0 hrs and $24 \mathrm{hrs}$ in Gelidium sp. and Eucheuma cottonii extract was shown in Table 1 and Table 2. The Reducing sugar ranges from $0.14 \%$ to $0.18 \%$. Reducing sugar value was low and did not show a difference value in $0 \mathrm{hrs}$ and $24 \mathrm{hrs}$ fermentation $(p<$ 0.05 ). This phenomenon was because the fermentation condition was not suitable yet for the starter to grow and can not hydrolyze the complex carbon from seaweed into the simple carbon like reducing sugar.

Table 1. Reducing sugar (\%) in Gelidium sp. extract during fermentation.

\begin{tabular}{ccc}
\hline \multirow{2}{*}{$\begin{array}{c}\text { Fermentation length } \\
\text { (hrs) }\end{array}$} & \multicolumn{2}{c}{ Starter (log CFU/mL) } \\
\cline { 2 - 3 } & L. plantarum & L. acidophilus \\
\hline 0 & $0.14 \pm 0.03^{\mathrm{a}}$ & $0.17 \pm 0.01^{\mathrm{a}}$ \\
24 & $0.14 \pm 0.04^{\mathrm{a}}$ & $0.16 \pm 0.02^{\mathrm{a}}$ \\
\hline
\end{tabular}

Values are presented as mean \pm SD. Values with different superscripts within the row are significantly different $(\mathrm{p}<$ $0.05)$. 
Table 2. Reducing sugar (\%) in Eucheuma cottonii extract during fermentation.

\begin{tabular}{ccc}
\hline \multirow{2}{*}{$\begin{array}{c}\text { Fermentation length } \\
\text { (hrs) }\end{array}$} & \multicolumn{2}{c}{ Starter $(\log$ CFU $/ \mathrm{mL})$} \\
\cline { 2 - 3 } & L. plantarum & L. acidophilus \\
\hline 0 & $0.17 \pm 0.05^{\mathrm{a}}$ & $0.17 \pm 0.03^{\mathrm{a}}$ \\
24 & $0.18 \pm 0.06^{\mathrm{a}}$ & $0.17 \pm 0.03^{\mathrm{a}}$ \\
\hline
\end{tabular}

Values are presented as mean \pm SD. Values with different superscripts within the row are significantly different $(\mathrm{p}<$ $0.05)$.

During fermentation, the starter's enzymes are expected to produce enzymes and hydrolyze the complex molecule into a simple molecule. For example, cellulose into glucose. Every enzyme has the optimum condition to hydrolyze the molecule. The factor that usually influences the enzyme activity is $\mathrm{pH}$, temperature, ion, and surfactant. When the conditions are not suitable, the enzyme activity will be low (Palavesam, 2015).

Table 1 and Table 2 show that the amount of reducing sugar was meager. The reducing sugar was only approximately $0.14 \%$ to $0.18 \%$. Low sugar content was challenging to support bacterial growth. Simple sugar is the most accessible source of energy to use during bacterial growth. L. plantarum and L. acidophilus are including a group of lactic acid bacteria. Lactic acid bacteria are fastidious. They need carbohydrates as well as other compounds to grow well (Singh et al., 2017). Total plate count (TPC) was lower than lactic acid bacteria count. It is showed that lactic acid bacteria growth was better than other bacteria in this fermentation. Lactic acid bacteria can suppress the development of different bacteria, although not optimal. During gain, lactic acid bacteria will produce acid and lower the $\mathrm{pH}$. The lower $\mathrm{pH}$ will stop the growth of other bacteria that cannot tolerate low $\mathrm{pH}$ to reduce the TPC value.

\subsection{Total plate count}

TPC is the enumeration of aerobic, mesophilic organisms included pathogens and non-pathogen, and is used to determine the hygienic status of food production. Bacterial count (TPC) on $0 \mathrm{hrs}$ and $24 \mathrm{hrs}$ in Gelidium sp. and Eucheuma cottonii extract were shown in Table 3 and Table 4 . The TPC of the sample ranges from $2.62 \log \mathrm{CFU} / \mathrm{mL}$ to $4.53 \log \mathrm{CFU} / \mathrm{mL}$. This data showed that the count of microorganisms other than the starter is still high. This is because not all ingredient used to produce the seaweed extract was sterilized, so the contamination was still very high.

In Gelidium sp. extract, TPC did not change after 24 hrs of fermentation in both starters. While in Eucheuma cottonii extract, TPC was increased 1 log cycle after $24 \mathrm{hrs}$ fermentation time. Eucheuma cottonii extract has higher reducing sugar $(p<0.05)$ that can support microorganisms' growth. Simple sugar, like reducing sugar, is easy to metabolize by microorganisms, including lactic acid bacteria as a starter and other bacteria present in the sample (Ficoseco et al., 2018). Table 1 and Table 2 show that the amount of reducing sugar was meager. The reducing sugar was only approximately $0.14 \%$ to $0.18 \%$. Low sugar content was challenging to support bacterial growth. Simple sugar is the most accessible energy source to use during bacterial growth (Singh et al., 2017).

Table 3. Total plate count in Gelidium sp. extract during fermentation.

\begin{tabular}{ccc}
\hline \multirow{2}{*}{$\begin{array}{c}\text { Fermentation length } \\
\text { (hrs) }\end{array}$} & \multicolumn{2}{c}{ Starter $(\log$ CFU/mL) } \\
\cline { 2 - 3 } & L. plantarum & L. acidophilus \\
\hline 0 & $3.29 \pm 0.06^{\mathrm{a}}$ & $3.86 \pm 0.25^{\mathrm{a}}$ \\
24 & $4.10 \pm 0.06^{\mathrm{a}}$ & $4.31 \pm 0.54^{\mathrm{a}}$ \\
\hline
\end{tabular}

Values are presented as mean \pm SD. Values with different superscripts within the row are significantly different $(\mathrm{p}<$ $0.05)$.

Table 4. Total plate count in Eucheuma cottonii extract during fermentation.

\begin{tabular}{ccc}
\hline \multirow{2}{*}{$\begin{array}{c}\text { Fermentation length } \\
\text { (hrs) }\end{array}$} & \multicolumn{2}{c}{ Starter $(\log$ CFU/mL) } \\
\cline { 2 - 3 } & L. plantarum & L. acidophilus \\
\hline 0 & $2.62 \pm 0.06^{\mathrm{a}}$ & $2.71 \pm 0.22^{\mathrm{a}}$ \\
24 & $4.52 \pm 0.05^{\mathrm{b}}$ & $4.53 \pm 0.06^{\mathrm{b}}$ \\
\hline
\end{tabular}

Values are presented as mean \pm SD. Values with different superscripts within the row are significantly different $(\mathrm{p}<$ $0.05)$.

\subsection{Viability of lactic acid bacteria starter}

Lactic acid bacteria count of the starter on 0 hrs and $24 \mathrm{hrs}$ in Gelidium sp. and Eucheuma cottonii extract was shown in Table 5 and Table 6 . The data ranges from $6.7 \log \mathrm{CFU} / \mathrm{mL}$ to $8.21 \log \mathrm{CFU} / \mathrm{mL}$. The bacterial count of starters increased after $24 \mathrm{hrs}$ of fermentation time in both seaweed and both starter $(p<0.05)$. It is showed that the starter could grow in seaweed extract. The increasing microbial count was about 1 log cycle.

Table 5. Viability of lactic acid bacteria in Gelidium sp. extract during fermentation.

\begin{tabular}{ccc}
\hline \multirow{2}{*}{$\begin{array}{c}\text { Fermentation length } \\
\text { (hrs) }\end{array}$} & \multicolumn{2}{c}{ Starter $(\log$ CFU/mL) } \\
\cline { 2 - 3 } & L. plantarum & L. acidophilus \\
\hline 0 & $6.73 \pm 0.14^{\mathrm{a}}$ & $7.13 \pm 0.16^{\mathrm{b}}$ \\
24 & $7.96 \pm 0.14^{\mathrm{c}}$ & $8.21 \pm 0.21^{\mathrm{c}}$ \\
\hline
\end{tabular}

Values are presented as mean \pm SD. Values with different superscripts within the row are significantly different $(\mathrm{p}<$ $0.05)$.

Eucheuma cottonii extract has higher reducing sugar $(p<0.05)$ that can support starter growth. Simple sugar is easy to metabolize by microorganisms, including lactic acid bacteria. Lactic acid bacteria are fastidious. It needs a carbon source like a simple sugar, a nitrogen source like amino acid or peptide, and some other compounds. 
Lack of carbon sources makes the microorganism's growth not optimal (Ficoseco et al., 2018). Estevam (2018) reported that the early fermentation time of fermented milk added with seaweed extract will increase the microbial count and titratable acidity.

Table 6. Viability of lactic acid bacteria in Eucheuma cottonii extract during fermentation.

\begin{tabular}{ccc}
\hline Fermentation length & \multicolumn{2}{c}{ Starter $(\log$ CFU $/ \mathrm{mL})$} \\
\cline { 2 - 3 } (hrs) & L. plantarum & L. acidophilus \\
\hline 0 & $6.85 \pm 0.15^{\mathrm{a}}$ & $6.70 \pm 0.23^{\mathrm{a}}$ \\
24 & $7.86 \pm 0.34^{\mathrm{b}}$ & $8.04 \pm 0.24^{\mathrm{b}}$ \\
\hline
\end{tabular}

Values are presented as mean \pm SD. Values with different superscripts within the row are significantly different $(\mathrm{p}<$ $0.05)$.

\section{$3.4 \mathrm{pH}$}

The $\mathrm{pH}$ sample on $0 \mathrm{hrs}$ and $24 \mathrm{hrs}$ in Gelidium sp. and E. cottonii extract were shown in Table 7 and Table 8 . The $\mathrm{pH}$ was decreased after fermentation $(p<0.05)$. These phenomena happen because the lactic acid bacteria starter was grown and converted the fermentation medium into lactic acid to lower the $\mathrm{pH}$.

The addition of aqueous seaweed extract to fermented milk will increase the total acid, thus will reduce the $\mathrm{pH}$ during the early fermentation period (Estevam et al., 2018). It showed that the starter could metabolize the carbohydrates in seaweed to produce lactic acid. Wu et al. (2007) showed that some lactic acid bacteria could use the oligosaccharides from some seaweed as a fermentation medium.

Table 7. $\mathrm{pH}$ in Gelidium sp. extract during fermentation.

\begin{tabular}{ccc}
\hline \multirow{2}{*}{$\begin{array}{c}\text { Fermentation length } \\
\text { (hrs) }\end{array}$} & \multicolumn{2}{c}{ Starter $(\log$ CFU $/ \mathrm{mL})$} \\
\cline { 2 - 3 } & L. plantarum & L. acidophilus \\
\hline 0 & $7.40 \pm 0.23^{\mathrm{a}}$ & $6.90 \pm 0.20^{\mathrm{b}}$ \\
24 & $5.90 \pm 0.10^{\mathrm{c}}$ & $5.53 \pm 0.05^{\mathrm{d}}$ \\
\hline
\end{tabular}

Values are presented as mean \pm SD. Values with different superscripts within the row are significantly different $(p<$ $0.05)$.

Table 8. pH in Eucheuma cottonii extract during fermentation.

\begin{tabular}{ccc}
\hline \multirow{2}{*}{$\begin{array}{c}\text { Fermentation length } \\
\text { (hrs) }\end{array}$} & \multicolumn{2}{c}{ Starter $(\log$ CFU $/ \mathrm{mL})$} \\
\cline { 2 - 3 } & L. plantarum & L. acidophilus \\
\hline 0 & $7.10 \pm 0.20^{\mathrm{a}}$ & $6.97 \pm 0.31^{\mathrm{a}}$ \\
24 & $5.63 \pm 0.23^{\mathrm{b}}$ & $5.50 \pm 0.36^{\mathrm{b}}$ \\
\hline
\end{tabular}

Values are presented as mean \pm SD. Values with different superscripts within the row are significantly different $(\mathrm{p}<$ $0.05)$.

Changes in $\mathrm{pH}$ value after $24 \mathrm{hrs}$ fermentation were different between starter $(p<0.05)$. The changes in $\mathrm{pH}$ that caused by acid production during bacterial growth is strain-specific characteristic. In this research, $L$. acidophilus $\mathrm{pH}$ was lower than L. plantarum. This result was the opposite with Solval et al. (2019), in which the lactic acid bacteria count in L. acidophilus was lower than L. plantarum; thus, $\mathrm{pH}$ in L. acidophilus was higher than L. plantarum.

\subsection{Phenol content}

Phenol content on 0 hrs and $24 \mathrm{hrs}$ in Gelidium sp. and Eucheuma cottonii extract were shown in Table 9 and Table 10. The phenol content showed various phenomena during the fermentation, and the value ranges are from 43.33 to 145.67 . In Gelidium sp. extract, the phenol content did not change after $24 \mathrm{hrs}$ of fermentation in both starters $(p<0.05)$. While in Eucheuma cottonii after $24 \mathrm{hrs}$ of fermentation, the sample with $L$. plantarum showed a lower phenol content but in L. acidophilus showed a higher phenol content than before fermentation $(p<0.05)$. Fermentation can increase the biological functionalities include antioxidant activity (Hifney et al., 2018).

Table 9 and Table 10 show phenol content in Gelidium sp. extract and Eucheuma cottonii extract before and after fermentation. In Gelidium sp. extract, the phenol content did not change after $24 \mathrm{hrs}$ of fermentation in both starters $(p<0.05)$. While in Eucheuma cottonii after $24 \mathrm{hrs}$ of fermentation, the sample with $L$. plantarum showed a lower phenol content but in L. acidophilus showed a higher phenol content than before fermentation $(p<0.05)$. Fermentation can increase the biological functionalities include phenol content and antioxidant activity (Hifney et al., 2018; Norakma et al., 2019). Microorganisms start to modify plant constituents during fermentation. Many biochemical changes occur during fermentation, leading to an altered ratio of healthy and anti-nutritive plants' components, which affect product properties such as bioactivity and digestibility (Katina et al., 2007). The microorganism growth during fermentation may hydrolyze the seaweed tissue, contributing to phenol Table 9. Phenol content in Gelidium sp. extract during fermentation.

\begin{tabular}{ccc}
\hline Fermentation length & \multicolumn{2}{c}{ Starter $(\log$ CFU/mL) } \\
\cline { 2 - 3 } (hrs) & L. plantarum & L. acidophilus \\
\hline 0 & $74 \pm 30^{\mathrm{a}}$ & $116 \pm 75^{\mathrm{a}}$ \\
24 & $116 \pm 8^{\mathrm{a}}$ & $137.5 \pm 6.5^{\mathrm{a}}$ \\
\hline
\end{tabular}

Values are presented as mean \pm SD. Values with different superscripts within the row are significantly different $(\mathrm{p}<$ $0.05)$.

Table 10. Phenol content in Eucheuma cottonii extract during fermentation.

\begin{tabular}{ccc}
\hline Fermentation length & \multicolumn{2}{c}{ Starter $(\log$ CFU/mL) } \\
\cline { 2 - 3 }$(\mathrm{hrs})$ & L. plantarum & L. acidophilus \\
\hline 0 & $70 \pm 19.29^{\mathrm{a}}$ & $91 \pm 5^{\mathrm{b}}$ \\
24 & $43.33 \pm 5.03^{\mathrm{c}}$ & $145.67 \pm 4.04^{\mathrm{d}}$ \\
\hline
\end{tabular}

Values are presented as mean \pm SD. Values with different superscripts within the row are significantly different $(\mathrm{p}<$ $0.05)$. 
increasing (Hifney et al., 2018). But it is also reported that not all substances are increased by fermentation. Several substances are also reduced after fermentation. The increment and reduction of phenolic content can be related to organic acids' metabolism, derivation of phenolics among themselves, and other metabolic pathways (Li et al., 2020).

\subsection{Antioxidant $I C_{50}$}

Antioxidant activity on 0 hrs and 24 hrs in Gelidium sp. and Eucheuma cottonii extract were shown in Table 11 and Table 12. The data showed that after fermentation, the sample has lower $\mathrm{IC}_{50}$ when compared to before fermentation. The antioxidant activity showed slightly higher after fermentation. These phenomena happen because the lactic acid bacteria starter was grown and converted the fermentation medium into lactic acid and other products that probably function as antioxidants. During fermentation, several microbial enzymes could hydrolyze the raw material and increase the phenol content (Cheng et al., 2015; Huang et al., 2017) and flavonoid content in seaweed fermentation (Hur et al., 2014). It will increase the antioxidant activity.

Table 11. Antioxidant $\mathrm{IC}_{50}$ in Gelidium sp. extract during fermentation.

\begin{tabular}{ccc}
\hline $\begin{array}{c}\text { Fermentation length } \\
\text { (hrs) }\end{array}$ & \multicolumn{2}{c}{ Starter $(\log$ CFU/mL) } \\
\cline { 2 - 3 } & L. plantarum & L. acidophilus \\
\hline 0 & $44667 \pm 378.37^{\text {ab }}$ & $45728.33 \pm 964.45^{\mathrm{b}}$ \\
24 & $43842.67 \pm 1372.15^{\text {ab }}$ & $42179.33 \pm 1941.45^{\mathrm{a}}$ \\
\hline
\end{tabular}

Values are presented as mean \pm SD. Values with different superscripts within the row are significantly different $(\mathrm{p}<$ $0.05)$.

Table 12. Antioxidant $\mathrm{IC}_{50}$ in Eucheuma cottonii extract during fermentation.

\begin{tabular}{ccc}
\hline $\begin{array}{c}\text { Fermentation length } \\
\text { (hrs) }\end{array}$ & \multicolumn{2}{c}{ Starter (log CFU/mL) } \\
\cline { 2 - 3 } & L. plantarum & L. acidophilus \\
\hline 0 & $44024.33 \pm 222.37^{\mathrm{a}}$ & $42872.33 \pm 986.28^{\mathrm{b}}$ \\
24 & $41504 \pm 855.89^{\mathrm{c}}$ & $38766.67 \pm 222.34^{\mathrm{c}}$ \\
\hline
\end{tabular}

Values are presented as mean \pm SD. Values with different superscripts within the row are significantly different $(\mathrm{p}<$ $0.05)$.

Antioxidant activity of fermented seaweed extract on $0 \mathrm{hrs}$ and $24 \mathrm{hrs}$ in Gelidium sp. and Eucheuma cottonii extract were shown in Table 11 and Table 12. Data $\mathrm{IC}_{50}$ is the concentration of a sample with the ability to scavenge $50 \%$ of DPPH radicals. The antioxidant activity of seaweed extract ranges from $44667 \%$ to $38766 \%$. This activity is still deficient. The data showed that after fermentation, it showed that the sample has a lower $\mathrm{IC}_{50}$. The antioxidant activity showed slightly higher after fermentation. These phenomena happen because the lactic acid bacteria starter was grown and converted the fermentation medium into lactic acid and other products that probably function as antioxidants. This data is also in line with the phenol content result (Table 9 and Table 10). After fermentation, the phenol content was slightly increased. During fermentation, several microbial enzymes could hydrolyze the raw material and increase the phenol content (Cheng et al., 2015; Huang et al., 2017) and flavonoid content in seaweed fermentation (Hur et $a l ., 2014)$ and increase the antioxidant activity.

\section{Conclusion}

Fermentation on a seaweed extract with $L$. acidophilus and L. plantarum increased lactic acid bacteria's viability, phenol content, antioxidant activity, and reduce $\mathrm{pH}$. However, the antioxidant activity was still low. Therefore, it needs to optimize the fermentation condition to obtain higher antioxidant activities.

\section{Conflict of interest}

The authors declare no conflict of interest.

\section{Acknowledgments}

This research was funded by the Faculty of Fisheries and Marine Science, Diponegoro University, Indonesia, in 2020 .

\section{References}

Aparicio, M.I., Martera, G., Goni, I., Villanueva-Suarez, M. and Redondo-Quenca, A. (2018). Chemical structure and molecular weight influence the in vitro fermentability of polysaccharide extracts from the edible seaweeds Himanthalia elongate and Gigartina pistillata. Food Hydrocolloids, 83(29), 348-354. https://doi.org/10.1016/j.foodhyd.2018.05.016

Cheng, J., Lee, S.K., Palaniyandi, S.A., Suh, J.W. and Yang, S.H. (2015). Effect of fermentation with monascus pilosus on the antioxidant activities and phenolic acid content of adzuki bean (Vigna angularis). Journal of Coastal Life Medicine, 3(4), 276-283.

Cui, M., Wu, J., Wang, S., Shu, H., Zhang, M., Liu, K. and Liu, K. (2019). Characterization and antiinflammatory effects of sulfated polysaccharide from the red seaweed Gelidium pacificum Okamura. International Journal of Biological Macromolecules, 129, 377-385. https://doi.org/10.1016/ j.ijbiomac.2019.02.043

Dissarapong, S., Benjakul, S., Visessanguan, W. and Kishimura, H. (2006). The influence of storage condition of tuna viscera before fermentation on the 
chemical, physical and microbiological changes in fish sauce during fermentation. Bioresources Technology, 97(16), 2032-2040. https:// doi.org/10.1016/j.biortech.2005.10.007

Estevam, A.C.T., Buriti, F.C.A., de Oliveira, T.A., Pereira, E.V.D.S., Florentino, E.R. and Porto, A.L.F. (2018). Aqueous extract of Gracilaria birdiae (Platino and Oliveira) as a texture modifier in fermented milks. LWT-Food Science and Technology, 90, 418-423. https://doi.org/10.1016/ j.lwt.2017.12.052

Ficoseco, C.A., Mansilla, F.I., Maldonado, N.C., Miranda, H., Nader-Macias, M.E.F. and Vignolo, G.M. (2018). Safety and growth optimization of lactic acid bacteria isolated from feedlot cattle for probiotic formula design. Frontiers in Microbiology, 9, 2220. https://doi.org/10.3389/fmicb.2018.02220

Hifney, A.F., Fawzy, M.A., Abdel-Gawad, K.M. and Gomaa, M. (2018). Upgrading the antioxidant properties of fucoidan and alginate from Cystoseira trinodis by fungal fermentation or enzymatic pretreatment of the seaweed biomass. Food Chemistry, 269, 387-395. https://doi.org/10.1016/ j.foodchem.2018.07.026

Hou, X., From, N., Angelidaki, I., Huijgen, W.J.J. and Bjerre, A. (2017). Butanol fermentation of the brown seaweed Laminaria digitata by Clostridium beijerinckii DSM-6422. Bioresource Technology, 238, 16-21. https://doi.org/10.1016/ j.biortech.2017.04.035

Huang, Q., Zhang, H. and Xue, D. (2017). Enhancement of antioxidant activity of Radix Puerariae and Red Yeast Rice by Mixed fermentation with Monascus purpureus. Food Chemistry, 226, 89-94. https:// doi.org/10.1016/j.foodchem.2017.01.021

Hur, S.J., Lee, S.Y., Kim, Y.C., Choi, I. and Kim, G.B. (2014). Effect of fermentation on the antioxidant activity in plant-based foods. Food Chemistry, 160, 346-356.

https://doi.org/10.1016/

j.foodchem.2014.03.112

Katina, K., Liukkonen, K.H., Kaukovirta-Norja, A., Adlercreutz, H., Heinonen, S.M., Lampi, A.M., Pihlava, J. M. and Poutanen, K. (2007). Fermentation induces changes in the nutritional value of native or geminated rye. Journal Cereal Science, 46(3), 348-355. https://doi.org/10.1016/ j.jcs.2007.07.006

Khani, M., Bahrami, A., Chegeni, A., Ghafari, M.D. and Zadeh, A.M. (2016). Optimization of carbon and nitrogen sources for extracellular polymeric substances production by Chryseobacterium indologenes MUT.2. Iranian Journal of Biotechnology, 14(2), 13-18. https:// doi.org/10.15171/ijb.1266

Li, S., Jin, Z., Hu, D., Yang, W., Yan, Y., Nie, X., Lin, J., Zhang, Q., Gai, D., Ji, Y. and Chen, X. (2020). Effect of solid-state fermentation with Lactobacillus casei on the nutritional value, isoflavones, phenolic acids and antioxidant activity of whole soybean flour. LWT-Food Science Technology, 125, 109264. https://doi.org/10.1016/j.lwt.2020.109264

Martin, A.B., Cuadrado, Y., Guerra, H., Gallego, P., Hita, O., Martin, L., Dorado, A. and Villalobos, N. (2000). Differences in the content of total sugars, reducing sugars, starch and sucrose in embryogenic and non-embryogenic calli from Medicago arborea L. Plant Science, 154(2), 143-151. https:// doi.org/10.1016/S0168-9452(99)00251-4

Mittal, R., Tavanandi, H.A., Mantri, V.A. and Raghavarao, K.S.M.S. (2017). Ultrasound assisted methods for enhanced extraction of phycobiliproteins from macro-algae, Gelidium pusillus (Rhodophyta). Ultrasonics Sonochemistry, 38, 92-103. https://doi.org/10.1016/ j.ultsonch.2017.02.030

Norakma, M.N, Zaibunnisa, A.H., Razarinah, W.W.R. and Karidah, S.M. (2019). enhancement and bioavailability of phenolic content in Kappaphycus alvarezii through solid substrate fermentation. Malaysian Journal of Fundamental and Applied Sciences, 15(6), 867-871.

Ozturk, B.Y., Gursu, B.Y. and Dag, I. (2020). Antibiofilm and antimicrobial activities of green synthesized silven nanoparticles using marine red algae Gelidium corneum. Process Biochemistry, 89, 208-219.

https://doi.org/10.1016/ j.procbio.2019.10.027

Palavesam, A. (2015). Investigation on lignocellulosic saccharification of haloalkaline solvent tolerant endo $-1,4 \quad \beta$-D -xylane from Halomonas neridiana APCMST-KS4. Biocatalysis and Agricultural Biotechnology, 4(4), 761-766. https:// doi.org/10.1016/j.bcab.2015.09.007

Parada, J., Perez-Correa, J. and Perez-Jimenez, J. (2019). Design of low glycemic response foods using polyphenols from seaweed. Journal of Functional Foods, 56, 33-39. https://doi.org/10.1016/ j.jff.2019.03.004

Rianingsih, L. and Sumardianto. (2020). Antioxidant activity in seaweed (Sargassum sp.) extract fermented with Lactobacillus plantarum and Lactobacillus acidophilus, presented at ICTCRED conference, Semarang (2019). IOP Conference Series: Earth and Environmental Science, 530, 012011. https://doi.org/10.1088/1755- 
Rodrigues, D., Walton, G., Sousa, S., Roche-Santos, T.A.P., Duarte, A.C., Freitas, A.C. and Gomes, A.M.P. (2016). In vitro fermentation and prebiotic potential of selected extract from seaweeds and mushrooms. LWT-Food Science and Technology, 73, 131-139. https://doi.org/10.1016/j.lwt.2016.06.004

Roohinejad, S., Koubaa, M., Barba, F.J., Saljoughian, S., Amid, M. and Greiner, R. (2017). Application of seaweed to develop new food products with enhanced shelf-life, quality and health-related beneficial properties. Food Research International, 99(Part 3), 1066-1083. https://doi.org/10.1016/ j.foodres.2016.08.016

Saravanan, S. and Parimelazhagan, T. (2014). In vitro antioxidant, antimicrobial and antidiabetic properties of polyphenols of Passiflora ligularis Juss. fruit pulp. Food Science and Human Wellness, 3(2), 5664. https://doi.org/10.1016/j.fshw.2014.05.001

Singh, V., Haque, S., Niwas, R., Srivastava, A., Pasupuleti, M. and Tripathi, C.K.M. (2017). Strategies for fermentation medium optimization: an in-depth review. Frontiers in Microbiology, 7, 2087. https://doi.org/10.3389/fmicb.2016.02087

Solval, K.M., Chouljenko, A., Chotiko, A. and Sathivel, S. (2019). Growth kinetics and lactic acid production of Lactobacillus plantarum NRRL B-4496, L. acidophilus NRRL B-4495, and L. reuteri B-14171 in media containing egg white hydrolysates. Food Science and Technology, 105, 393-399. https:// doi.org/10.1016/j.lwt.2019.01.058

Suleria, H.A.R., Gobe, G., Muasci, P. and Osborne, S.A. (2016). Marine bioactive compounds and health promoting perspectives; innovation pathways for drug discovery. Trends in Food Science and Technology, 50, 44-55. https://doi.org/10.1016/ j.tifs.2016.01.019

Suraiya, S., Lee, J.M., Cho, H.J., Jang, W.J., Kim, D., Kim, Y. and Kong, I. (2018). Monascus spp. fermented brown seaweeds extracts enhance biofunctional activities. Food Bioscience, 21, 90-99. https://doi.org/10.1016/j.fbio.2017.12.005

Tanod, W.A., Dewanto, D.K., Ndobe, S., Riyadi, P.H. and Putra, M.Y. (2019). Screening of antibacterial and antioxidant activity from the soft corals Sinularia sp. and Sarcophyton sp. origin Palu bay, Central Sulawesi, Indonesia. Squalen Bulletin of Marine and Fisheries Postharvest and Biotechnology, 14(2), 73-83. https:// doi.org/10.15578/squalen.v14i2.394

Uchida, M., Kurushima, H., Ishihara, K., Murata, Y., Touhara, K., Ishida, N., Niwa, K. and Araki, T. (2017). Characterization of fermented seaweed sauce prepared from nori (Pyropia yezoensis). Journal of
Bioscience and Bioengineering, 123(3), 327-332. https://doi.org/10.1016/j.jbiosc.2016.10.003

Wang, Q., Ye, H., Sen, B., Xie, Y., He, Y. and Park, S. (2018). Improved production of docosahexaenoic acid in batch fermentation by newly-isolated strains of Schizochytrium sp. and Thraustochytiidae sp. through bioprocess optimization. Synthetic and Systems Biotechnology, 3(2), 121-129. https:// doi.org/10.1016/j.synbio.2018.04.001

Wu, S.C., Wang, F.J. and Pan, C.I. (2007). Growth and survival of lactic acid bacteria during fermentation and storage of seaweed oligosaccharides solution. Journal of Marine Science and Technology, 15(2), 104-114.

Zhao, C., Yang, C., Liu, B., Lin, L., Sarker, S.D., Nahar, L., Yu, H., Cao, H. and Xiao, J. (2018). Bioactive compounds from marine macroalgae and their hypoglycemic benefits. Trends in Food Science and Technology, 72, 1-12. https://doi.org/10.1016/ j.tifs.2017.12.001 